\title{
Genetic variability of three cassava traits across three locations in Ghana
}

\author{
Peprah Bright Boakye ${ }^{1^{*}}$, Ofori Kwadwo ${ }^{2}$, Asante Isaac $\mathrm{K}^{3}$ and Elizabeth Yaa Parkes ${ }^{1,4}$ \\ ${ }^{1}$ Crops Research Institute, Fumesua, Kumasi, P. O. Box 3785, Ghana. \\ ${ }^{2}$ Department of Crops Science, University of Ghana, Legon. \\ ${ }^{3}$ Department of Botany, University of Ghana, Legon. \\ ${ }^{4}$ International Institute of Tropical Agriculture, Ibadan, Nigeria.
}

Accepted 27 May, 2013

\begin{abstract}
A study was conducted to assess the extent of genetic variability, broad-sense heritability and correlations for fresh root weight, root number and top weight of five cassava genotypes across three locations in 2 years. Combined analysis of variance revealed highly significant genotypic effect for all the traits. Genotype $x$ environment interaction was also significant for all the traits studied indicating considerable but, varying response of the genotypes to the environments. High broad-sense heritability and genetic advance as percent of the mean were observed for fresh root weight, suggesting that the trait is primarily under genetic control and that a simple recurrent phenotypic selection scheme would be rewarding. Phenotypic coefficients of variation values were larger than their corresponding genotypic coefficient of variation values for all traits. Correlations between the three traits were highly significant and positive indicating that simultaneous progress for the three traits is feasible.
\end{abstract}

Key words: Ghana, Manihot esculenta, cassava traits, genotypes.

\section{INTRODUCTION}

Cassava (Manihot esculenta Crantz) is a food security crop for most of the populations in the tropical regions of the world (Akinwale et al., 2010a). Cassava plays an important role in Ghana's economy contributing $16 \%$ 'agricultural gross domestic product' (Safo- Kantanka, 2004). Breeding efforts are focusing on the improvement on yield potentials and quality traits through development of cassava genotypes. Many of the economic traits of cassava are quantitatively inherited and are highly influenced by environmental conditions (Akinwale et al., 2010a). This necessitates partitioning of the overall variability into its heritable and non- heritable components with the use of suitable genetic parameters such as genotypic coefficient of variation, heritability estimates, genetic advance and phenotypic variances for traits
(Table 2). It serves as a predictive role in selection procedures (Allard, 1960). The objective of this paper is to evaluate the extent of genetic variability, heritability and advances of cassava fresh root weight, root number and top weight in three agro-ecological zones of Ghana.

\section{MATERIALS AND METHODS}

The study was carried out at three locations- Fumesua $(277 \mathrm{~m}$ absl), Ejura (240 m absl) and Pokuase (65 $\mathrm{m}$ absl) for two growing seasons (2009/2010 and 2010/2011) in Ghana. Five cassava genotypes (dl107/005, dl107/006, dl107/009, la07/007 and la07/026) developed by the CSIR-Crops Research Institute (CSI$\mathrm{CRI}$ ) were used for the study. The experimental materials were planted in randomized complete block design with three replications 
Table 1. Mean square for data combined from 3 locations over 2 years.

\begin{tabular}{|c|c|c|c|c|}
\hline \multirow[b]{2}{*}{ Source } & \multirow[b]{2}{*}{ df } & \multicolumn{3}{|c|}{ Mean squares } \\
\hline & & Root number & Root weight & Top weight \\
\hline Genotype & 4 & $1836.8^{* \star *}$ & $723.0^{* * *}$ & $1054.1^{\star \star *}$ \\
\hline Location & 2 & $2592.0^{\star \star \star}$ & $359.8^{*}$ & $579.7^{\star}$ \\
\hline Year & 1 & $24.5 n s$ & $4616.8^{* * *}$ & $9345.2^{\star \star \star}$ \\
\hline Genotype $\times$ location & 8 & $1096.9^{* *}$ & $364.0^{* *}$ & $654.4^{* * *}$ \\
\hline Genotype $\times$ year & 4 & $448.7 \mathrm{~ns}$ & $84.4 \mathrm{~ns}$ & $257.8 \mathrm{~ns}$ \\
\hline Location year & 2 & $1046.1^{*}$ & $205.8 \mathrm{~ns}$ & $242.1 \mathrm{~ns}$ \\
\hline Genotype $\times$ location $\times$ year & 8 & $212.8 \mathrm{~ns}$ & $176.4 \mathrm{~ns}$ & $85.1 \mathrm{~ns}$ \\
\hline Error & 58 & 330.2 & 106.0 & 117.5 \\
\hline
\end{tabular}

Ns: not significant; ${ }^{*},{ }^{* *},{ }^{* * *}$ : significant at $5 \%, 1 \%$ and $0.1 \%$ respectively.

Table 2. Variance components for cassava traits score over 6 environments.

\begin{tabular}{|c|c|c|c|c|c|c|}
\hline Traits & $\sigma_{g}^{2} g$ & $\sigma_{p}^{2}$ & $\sigma_{g y}^{2}$ & $\mathrm{O}_{\mathrm{g}}^{2}$ & Oे $^{2}$ gly & $\mathbf{O}_{\mathrm{e}}^{2}$ \\
\hline Number of roots & 28.00 & 59.20 & 26.20 & 147.35 & 39.13 & 330.20 \\
\hline Root weight & 25.06 & 40.18 & 10.20 & 31.27 & 23.47 & 106.00 \\
\hline Top weight & 12.60 & 58.56 & 19.19 & 94.88 & 10.80 & 117.50 \\
\hline
\end{tabular}

Table 3. Coefficients of variation, heritability and genetic advance for traits.

\begin{tabular}{lccccc}
\hline Traits & Mean & $\mathbf{G C V}$ & $\mathbf{P C V}$ & $\mathbf{h}^{2} \mathbf{b}$ & $\mathbf{G A}_{\mathbf{s}}$ \\
\hline Number of roots & 59.2 & 8.94 & 12.83 & 48.60 & 12.84 \\
Root weight & 28.0 & 17.88 & 22.64 & 62.40 & 29.10 \\
Top weight & 31.7 & 11.20 & 24.10 & 21.50 & 13.50 \\
\hline
\end{tabular}

GCV = genotypic coefficient of variation, PCV = phenotypic coefficient of variation, $h^{2} b=$ broad sense heritability and GAs = genetic advance as a percent of the mean.

in the field. Each plot consisted of 4 rows of 40 plants at a spacing of $1 \times 1 \mathrm{~m}$ within and between rows. The experiment was conducted under rain-fed conditions without fertilizers or any other agrochemicals applications. Harvesting was done at 12 months after planting for each location and season. The two inner rows of each plot were used to collect data for fresh root weight (FRW), root number (RW) and top weight (TW). Data were subjected to analysis of variance ANOVA using Genstat 9.2 version (VSN Ltd, UK). Traits component and magnitude of variation responsiveness to selection was calculated based on Okwuagwu et al. (2008). Expected genetic advance of the mean for each trait was calculated according to Allard (1960).

\section{RESULTS AND DISCUSSION}

Combined analysis of variance showed significant variability for all traits for genotype main effect (Table 1). Variability among the genotypes is adequate for selection for the desired traits leading to significant progress in cassava improvement programs. Akinwale et al. (2010a) reported similar results for the traits study. The magnitude of phenotypic coefficient of variation was higher than genotypic coefficient of variation among all the traits studied (Table 3 ). Variation among genotypes is not only genotypic in nature but influenced by the environment. This finding is in agreement with earlier observations by Aina (2007) and Akinwale et al. (2010a). The high broad-sense heritability recorded for root weight indicate a high genetic variance with additive and nonadditive effects. The magnitude of heritability of a given trait is affected by the type of genetic material involved (Ceccarelli, 1994). Cassava, a vegetatively propagated crop has the advantage of genes being fixed in a new hybrid. Kawano et al. (1998) suggested that heritability of cassava after hybridization is mainly broad-sense in nature. Heritability estimates were high $(>0.50)$, medium (0.30 to 0.50) and low (<0.30) (Bhateria et al., 2006).

High broad sense heritability coupled with high genetic advance (Table 3) for root weight can aid selection for the trait as Pradeepkumar et al. (2001) suggested that high broad- sense heritability alone does not always entail better selection. Correlations between fresh root weight and root number were highly significant and positive (Table 4) indicating that simultaneous progress for the two traits is feasible (Akinwale et al. 2010b). 
Table 4. Phenotypic correlation coefficient for 5 cassava in 6 environments.

\begin{tabular}{llll}
\hline & Number of roots & Root weight & Top weight \\
\hline Number of roots & 1.00 & & \\
Root weight & $0.64^{* * *}$ & 1.00 & \\
Top weight & $0.27^{*}$ & $0.08 \mathrm{~ns}$ & 1.00 \\
\hline
\end{tabular}

\section{Conclusions}

1) High broad- sense heritability value with high genetic advance observed for fresh root weight suggest simple recurrent phenotypic selection scheme can be helpful. 2) Improvement of traits such as fresh root weight and root number simultaneously is possible with this population.

\section{ACKNOWLEDGEMENTS}

We are grateful to Generation Challenge Program for funding this work. We are also grateful to Dr. Emmanuel Okogbenin, Dr. C. Egesi, Mrs Adelaide Agyeman and Mrs Felicity Ababio for their support.

\section{REFERENCES}

Aina FA (2007). Genetic variability in cassava as influenced by root yield in Nigeria. J. Biol. Sci. 2(5):765-770.

Akinwale MG, Akinyele BO, Dixon AGO, Odiyi AC (2010a). Genetic variability among forty- three cassava genotypes in three agroecological zones of Nigeria. J. Plant Breed. Crop Sci. 2(5):104-109.

Akinwale MG, Aladesanwa RD, Akinyele BO, Dixon AGO, Odiyi AC (2010b). Inheritance of beta- carotene in cassava (Manihot esculenta Crantza). Int. J. Genet. Mol. Biol. 2(10):198-201.

Allard RW (1960). Principle of plant breeding. John Wiley and Sons Co. New York. p. 485.

Bhateria S, Sood SP, Pathania A (2006). Genetic analysis of quantitative traits across environments in Linseed (Linum ustitatissimum L). Euphytica 150(1-2):185-194.
Ceccarelli S (1994). Specific adaption and breeding for marginal conditions. Euphytica 77:205-219.

Kawano K, Narintaraporn K, Narintaraporn P, Sarakorn S, Lamsila A, Limsilla J, Suparhan d, Sarawat V, Watananonta W (1998). Yield improvement in a multistage breeding program for cassava. Crop Sci. 38:325-332.

Okwuagwu CO, Okoye MNM, Okolo EC, Ataga CD, Uguru MI (2008). Genetic variability of fresh fruit bunch yield in Deli/dura $x$ tenara breeding population of oil palm (Elaeis guineenis Jacq) in Nigeria. J. Trop. Agric. 46(1-2):52-57.

Pradeepkumar T, Bastian D, Joy M, Radharkrishnam NV, Aipe KC (2001). Genetic variation in tomato for yield and resistance to bacterial wilt. J. Trop. Agric. 39:157-158.

Safo-Kantanka O (2004). Cassava can replace cocoa in Ghana I and II. Daily Graphic May 11-12, No. 149123 and 149124, p. 9. 